\title{
Frederik Pio
}

\section{Den transnationale uddannelsesrevolutions opløsning af pædagogikkens egenart \\ Om OECDs hvidvask af pædagogikkens begreber om: professionalitet, laring, autenticitet og dannelse}

\begin{abstract}
[English Title: The transnational educational revolution and its disruption of the specificity of general pedagogy: On the OECD-laundering of the pedagogical concepts of 'professionalism', 'learning', 'authenticity' and 'Bildung'].

Any attempt to identify the basic principles of a general pedagogy (allgemeine Pädagogik) must touch upon the question of what comprise the basic and fundamental constituents of pedagogy as a field of knowledge. Thus I seek to adress the question of the specificity of pedagogy. In this perspective, pedagogy is brought into contact with its own foundation as a cultural task, rooted in a European tradition in which we are cultivated. In this way, the recreation of civilizational tradition is at the same time addressed as part of the purpose of pedagogy.

The article sets out to discuss the current plight of general pedagogy, with particular attention to the transnational trend towards top-down educational governance over the last 25-30 years. This is achieved by analyzing the so-called 'antinomies' (the pedagogical paradox), which have been described by several educational researchers as foundational for modern pedagogy (Uljens; Løvlie; Biesta; Oettingen; Schaffar and Benner).

I discuss these pedagogical antinomies as nested within specific pedagogical problems concerning knowledge, value, institution and action. I hereby demonstrate how the transnational educational revolution of the last 25-30 years has hollowed out and made one-dimensional the (originally thick and multidimensional) general pedagogical understanding of the concepts of 'professionalism', 'learning', 'authenticity' and 'Bildung'. These elements gather into a narrative, telling the story of a transnational dismantling of the basic conception of a general and culturally anchored pedagogy.
\end{abstract}

Keywords

$O E C D, E U$, professionalism, learning, authenticity, Bildung

\section{Indledning}

Den almene pædagogik er ikke selv en specifik pædagogisk tilgang. Den er en metadisciplin som udgør en refleksion over, det fælles pædagogiske udgangspunkt på tværs af mange forskellige typer af pædagogisk kundskab. Den udgør en refleksiv adressering af spørgsmålet om, hvordan kan det invariant pædagogiske beskrives på tværs af alle mulige forskel-

Frederik Pio, Aarhus Universitet, Danmark

e-mail:frpi@edu.au.dk

Studier i Predagogisk Filosofi | https://tidsskrift.dk/spf/index | ISSN nr. 22449140 
lige pædagogiske praksisser, institutioner og opgavetyper. En indkredsning af det almene i pædagogikken må dermed berøre spørgsmålet om noget pædagogisk set fundamentalt og grundlæggende. Dvs. spørgsmålet om pædagogikkens egenart.

Refleksionen af det almene i pædagogikken bliver i dette perspektiv et nødvendigt udgangspunkt for mere specialiserede pædagogiske tilgange. Pædagogikken bliver her sig sit grundlag bevidst som en kulturopgave forankret i den europæiske tradition vi er rundet af. Her bryder civilisations-begrebet samtidig ind i tænkningen. For pædagogik handler om livsformer. Dvs. en forståelse af pædagogik som noget der udspringer af livet selv, som Mollenhauer er inde på det:

"Vi kan ikke udslette os selv som samfundsmennesker, vi kan ikke indtage en død eller neutral stilling. Det er rigtig nok en trivialitet, men dette er samtidig det primære og mest alvorlige pædagogiske sagsforhold. Opdragelse er frem for alt overlevering, meddelelse af det som er vigtigt for os selv. Der kan ikke tænkes nogen pædagogisk handling hvor den voksne ikke meddeler noget om sig selv og sin livsform, med vilje eller uvilkårligt".

Mennesket og de dertil knyttede livsprocesser er selvbegrundende. Dvs. livet skal ikke begrunde sig i forhold til noget andet. Dvs. livets mål er ultimativt mere liv i form af en løbende genskabelse af sig selv. Hele denne selvfornyende proces, gør det klart, at pædagogikkens grundfænomener ligger indbagt i genskabelsen af de kulturelle livsprocesser selv. Menneskets fortløbende formning af sig selv ligger nedlagt i dynamiske begreber om læring, tilpasning, omstillelse, fornyelse, forandring, kommunikation, transformation, overlevering, initiering, i hævdholdelse og tradering. Dvs. i den ældre generations villen-noget med den yngre generation. For så vidt det altså er livsprocesser der væver i disse begreber, så er det også pæedagogiske processer der strømmer i de menneskelige livsformers omhu for deres egen fortsættelse og kontinuitet. Pædagogikken ligger med andre ord indbagt helt nede i den menneskelige livsverdens kulturelle genskabelse af sig selv.

Pædagogiske grundfænomener er dermed konstituerende for livets selvfornyelse, og dermed for livets opstand mod døden. Dermed består der her en parallel mellem pædagogikken og medicinen: den medicinske videnskab beror på en intention om at afværge og udsætte døden længst muligt. Pædagogikken beror i stedet på en intention om at fremme livsprocessernes fortløbende genskabelse af sig selv mhp. mere liv. Så medicinen er som døds- (afværgende) videnskab en form for tvilling til pædagogikken som livs- (genskabende) kundskab.

Jeg vil perspektivere på den almene pædagogiks aktuelt pressede tilstand, i lyset af de centrale, transnationale udviklingstendenser inden for uddannelsesstyring der har gjort sig gældende de sidste ca. 25-30 år. Dette vil jeg gøre, ved at tage afsæt i de antinomier, som en række pædagogiske forskere har forholdt sig til som definerende for moderne pædagogik. Denne tematik er blevet sat på dagsordenen af aktuelle uddannelsesforskere som bl.a. Ale-

1 Klaus Mollenhauer. Glemte sammenhenger (Oslo: Ad Notam, 1996), 22. 
xander von Oettingen; Michael Uljens; Lars Løvlie; Gert Biesta, Birgit Schaffar og Dietrich Benner.

Oettingen ser nærmere bestemt spørgsmålet om pædagogisk professionalitet som spaltet i fire antinomiske paradokser, der angår (i) Rationalisering (sociologi); (ii) Pluralisering (kultur); (iii) Individualisering (psykologi) og (iv) Civilisering (natur, filosofi). ${ }^{2}$ Disse pædagogiske paradoksaliteter har en rod bl.a. hos Kant, Rousseau og Herbart.

Jeg vil gennem fokusering af disse pædagogiske antinomier eller paradokser (omkring pædagogikkens videns-, værdi-, institutions- samt handlings-problem, jf. Oettingen: 2010) vise, hvorledes den transnationale uddannelsesrevolution de sidste 25-30 år har udtyndet og en-dimensionaliseret den almenpædagogiske bestemmelse af begreber om professionalitet, laring, autenticitet og dannelse. Samlet løber disse elementer sammen i en fortælling om et transnationalt opgør de sidste 25-30 år med forestillingen om en almen pædagogik. Man kan værdisætte dette opgør på forskellige måder. Ærindet for artiklen er overvejende at rapportere til offentlighedens kendskab, at dette opgør finder sted.

Nedenfor vil jeg altså gennemspille de pædagogiske begreber:

I. Professionalitet (ift. videns-problemet)

II. Læring (ift. handlings-problemet),

III. Autenticitet (ift. institutions-problemet)

IV. Dannelse (ift. værdi-problemet)

Jeg vil fokusere de almenpædagogiske problemstillinger der kendetegner disse begreber. Dette for at vise, hvorledes den transnationale uddannelsesstyring i dette lys udgør en bekymrende afvikling eller sammenklapning af pædagogikkens almene grundtræk. Artiklen bidrager dermed ind i et mere overgribende emne, der handler om, hvilke konsekvenser der aftegner sig for vor tids stadig mere specialiserede pædagogiske viden, hvis man endegyldigt skiller sig af med pædagogikken i dens almene udgangspunkt.

\section{Viden (mellem nærhed og distance)}

\section{a) Globalisering: viden som vare}

I den klassiske pædagogik var kernefigurerne tænkere i form af konkrete personer (eks. Schleiermacher, Rousseau og Kant). I den aktuelle konjunktur (ca. fra Maastricht traktaten fra 1993 frem til i dag) udgøres kernefigurerne i dag mere af ansigtsløse policy-dokumenter konstrueret af af-personaliserede makro-institutioner med EU og OECD i centrum af et komplekst institutionsnetværk. Det er fra disse institutionsaktører at dén helt dominerende uddannelsestænkning er kommet den sidste generation. ${ }^{3}$ Uddannelsestænkningen

2 Hans Jørgen Kristensen \& Per Fibæk Laursen, eds. Gyldendals pæedagogik håndbog (København: Gyldendal, 2012), 531-549.

3 Ove Korsgaard, Jens Erik Kristensen \& Hans Siggaard Jensen. Paedagogikkens idehistorie (Århus: Århus Universitetsforlag, 2017), 373. 
er i dag præget af kvantitative tilgange, der understøtter et omkransende, transnationalt program for policyudvikling.

Dagsorden er her at måle uddannelseskvalitet i et globalt perspektiv op mod transnationale standarder. ${ }^{4}$ Præmissen er, at uddannelse nu ses som et fuldstændigt integreret element $\mathrm{i}$ et lands økonomi. ${ }^{5}$ Rationalet for denne vending ligger ved en ny logik, hvor uddannelse bestemmes som den altdominerende nøgle til den enkelte nations evne til at klare sig i den globale markedskonkurrence. Man kan her pege på OECD (1996) Measuring what people know. Human capital accounting for the knowledge economy.

Den foregående kommissionsformand Emanuel Barosso talte som kommisær således heller ikke om 'samfund' (som eks. 'det danske samfund'). Det er for kultur-tonet. I stedet tales der om 'økonomier'.6 Så her er EU og OECD helt på linje. Danmark er med sine uddannelser frem for alt en økonomi. Den underliggende politiske antagelse er, at alle andre faktorer for et lands trivsel, udvikling og lykke nu er underordnet uddannelsesområdet som det afgørende vækstparameter. Dvs. viden bestemmes her som den centrale kilde til økonomisk vækst. En nations økonomiske udkomme bliver dermed knyttet til distribution og udvikling af viden i dets uddannelsessystem. Dette fører til en skærpet opmærksomhed på uddannelsessystemer i alle vestlige lande, med særlig henblik på et ønske om at sammenligne disse systemer indbyrdes. Problemet er, at dermed reduceres uddannelse potentielt til et spørgsmål om smøring eller vækstfremme af de nationale, økonomiske systemer.

I tråd med dette har Europa Kommissionen også besluttet at overflytte hele uddannelsesområdet i EU fra det gamle kulturområde til det nye område for services, varer og toldregler. ${ }^{7}$ Med uddannelse og pædagogik skubbet ind i denne altdominerende rolle som en vare eller service, så er det slut med friheden som ideal for uddannelsessystem og skole. I stedet skal vi have lighed. Dette er det store skifte.

Det ideal om først og fremmest frihed der siden pædagogikkens oplysnings-humanistiske vending har knyttet sig til europæisk uddannelse og opdragelse med Kant (myndighed), Rousseau (menneskets ubestemte perfektibilitet) Humboldt (forsknings-autonomi), Herbart og Schleiermacher (Bildsamkeit) bliver nu gradvis fjernet og erstattet af et helt andet politisk ideal. Nemlig idealet om lighed (equity). ${ }^{8} \mathrm{Og}$ for at få transnational lighed skal vi have styring og standardisering. Idealet om lighed erstatter dermed det gamle ideal om frihed. Og denne erstatning implementeres under EUs banner af centraliseret standardisering ( $\mathrm{i}$ transnational forstand) og styring (på det nationale niveau). Man ser her fremkomsten af nye styringsformer, der kombinerer new speak om decentralisering og autonomi med nye mere omfattende kontrolregimer (som benchmarking, kvantitative test, NPM).

4 H.-D Meyer, R. Strietholt \& D.Y. Epstein. Three models of global education quality. The emerging democratic deficit in global education governance. Retrieved march 2018 at www.researchgate.net, 132.

5 Op.cit., 139.

6 Lejf Moos. Pæedagogisk ledelse i en laringsmålstyret skole? (København: Hans Reitzel, 2016), 84.

7 Op.cit., 84.

8 OECD. Education policy analysis. 2002, kap. 2. 
Den meget brede baggrund for denne udvikling har at gøre med processer, der for alvor tager fart ved indgangen til 1990erne. Omkring den elite der globalt dominerer politik, økonomi, administration, jura og medier etablerer der sig - i de sidste årtier af det 20. århundrede - en konsensus om, at en kraftigt øget globalisering er at foretrække. ${ }^{9}$ Denne klasse ser, at den kan sikre sine egne interesser gennem en kraftigt øget globalisering. Dette realiseres gennem en accellereret konstruktion af et overstatsligt institutionsnetværk, der gennem sin uddifferentiering gradvis fremstår mere og mere adskilt fra rørelser i de suveræne nationalstaters parlamentarisk-folkelige undergrund..$^{10}$

I takt med at dette magtfulde og overnationale institutionsnetværk (bl.a. EU, WTO, IMF, World Bank, OECD, UNESCO, G8) øger sin kompleksitet, mister det imidlertid også sin folkelige-demokratiske legitimitet. ${ }^{11}$ Flere og flere beslutninger flyttes væk fra de nationale parlamenter. Man accellererer her udviklingen af et trans- og overnationalt institutionsnetværk med en underskov af tilhæftende organisationer. EU og OECD bliver her to særdeles vigtige knudepunkter i denne netværksbaserede styring af uddannelsessektoren i Europa og mere globalt. Det er en netværks-organisering man har med at gøre her. Men ikke desto mindre peger en lang række undersøgelser på, at det isæer er OECD og EU (særligt Europa Kommissionen) der de sidste ca. 20 år har øget presset på de nationale uddannelsessystemer.

Man kan ikke sige at det nationalstatslige bidrag til det europæiske fællesskab her bliver direkte erstattet af en transnational union. Man må snarere se en situation, hvor EU som 'netværksstat' (Moutsios: 2013) operationaliserer den enkelte nationalstat, ved at gøre denne til et vehikel for en definitionsmagt, der er støbt dybt i det transnationale institutionsnetværk og sedimenteret i uddannelsespolicy, der distribueres og nationalstatsligt realiseres via OECD og PISA. EU kan ikke direkte lovgive for nationale uddannelser, men fra EU og OECD udøves der en "blød styring"."12 Dette sker gennem distribution af sociale teknologier nedlagt i bl.a. OECDs nationale uddannelsesreviews og anbefalinger. Dette formidles via transnationale sammenligninger af kvantitative uddannelsesindikatorer, der tager sig forførende objektive ud og dermed fremstiller en facade af tilsyneladende sandhed, der ser sig selv som datadrevet og dermed renset for normativitet.

Dette gøres på bl.a. den måde, at man gennem en række policy analyser og nationale Reviews - ex. Danmark (2004); Sverige (2015) - foranlediger en stribe grundskolereformer med hovedvægten på en stadig øget målrationel styring efter kompetencebeskrevne læringsmål. ${ }^{13}$ Kernedokumenter i denne proces er udover de nationale PISA-afrapporterin-

9 Christopher Lasch. Eliternes oprør (Viborg: Hovedland, 1996), 47ff; Scruton, Roger. "Paris erklæringen.". Retrived march 2018 at https://thetrueeurope.eu/a-europe-we-can-believe-in/

10 Stavros Moutsios. "The de-Europeanization of the university under the Bologna Process," Thesis Eleven 119, no. 1 (2013): 22-46.

11 Chris Rumford. “European civil society of Transnational space?," European Journal of Social Theory 6, no. 1 (2013): 25-43; L. Vesnic-Alucevic \& R.C. Nacarino. "The EU and its democratic deficit and (possible) solutions," European view 11 (2012): 63-70.

12 Moos, Padagogisk ledelse i en laringsmålstyret skole, 55.

13 I Danmark knæsættes Fælles Mål (2001), Klare Mål (2003) og Forenklede Fæelles Mål (2014). 
ger, OECDs Education policy analysis (2002). Med sine nationale reviews går OECD væsentlig længere med sine anbefalinger til nationale uddannelsessystemer end eksempelvis UNESCO og IEA gør det. ${ }^{14}$ I det danske review af skolen fra 2004 vedgår OECD således at der er tale om "dristige forslag"15 men går alligevel videre, med understregning af at "det er bydende nødvendigt at folkeskolens nuværende kultur ændres". ${ }^{16}$ Det der skal underkastes reformer er fundamentale hovedområder som: skolens evalueringskultur, skoleledelsen, læreruddannelsen, lærernes overenskomst og timetal samt vigtigheden af mere globalisering i form af mere støtte til tosprogede elever (kap. 1). Det er PISA-data samt OECDs normer og reviews der konsekvent lægges til grund for denne 'bydende nødvendighed' af reformer. Styringen her er altså 'blød'. Der er formelt set tale om "anbefalinger" - men ikke desto mindre "bydende nødvendige" anbefalinger. Disse anbefalinger får karakter af bløde policy instrukser henvendt til den nationale centraladministration.

Gennem dette bløde pres fastholdes en af OECD økonomisk defineret udviklingsretning for de nationale uddannelsessystemer. Pointen er, at den transnationale, bløde styring omsat ned til det nationale niveau hurtigt kan blive til hård styring. Her har man i Danmark op gennem 00erne netop set betydelige dele af OECDs nationale anbefalinger blive omsat til hård lovgivning. Som hængsel mellem det bløde, transnationale, dagsordensættende pres ( $\mathrm{i}$ form af 'anbefalinger') på den ene side og den hårde nationale lovgivning på den anden side, der spiller Moderniseringsstyrelsen en helt central rolle fra dens stiftelse med B. Corydon i 2011.

Det transnationale organisationsnetværk snylter dermed på de nationale parlamenter, i den forstand at det nemt udadtil kommer til at se ud som om, ideerne kommer fra det nationale niveau, selv om den grundlæggende policy strukturelt set er støbt i transnationale fora - dvs. uden for demokratisk kontrol. Moderniseringsstyrelsen bliver - under dens tidligere navn som $\varnothing$ konomistyrelsen - dermed op gennem 00'erne ekspeditionskontor for disse transnationale agender, hvor det er et åbent spørgsmål, om disse har en tilstrækkelig folkelig legitimitet. ${ }^{17}$ Et eksempel er det forhadte lovindgreb om lærernes arbejdstid fra 2013 orkestreret af KL og Thorning-Schmidt regeringen i 2013. Men det oprindelige ideudspil til denne dagsorden kom fra OECD og lå som en separat, eksplicit anbefaling i det nationale review allerede i $2004 .^{18}$

Dette er altså et eksempel på at der er skabt et overstatsligt koordineret netværk af institutioner, der som transnationalt i praksis gennemtrænger og omkalfatrer nationalstater med en definitionsmagt, det i praksis ikke rigtigt er muligt for de social-liberale, centrum-venstre partier at frasige sig på nationalt niveau. ${ }^{19}$ For OECD er blot budbringeren der kommer med nyt fra en spirende transnational magtelite. Dette ytrer sig som en form for

14 Meyer, Strietholt \& Epstein, Three models of global education quality, 143.

15 OECD. Review af den danske folkeskole. 2004, 127.

16 Op.cit., 127, kursiv fp.

17 Kasper Støvring. Fortællingen om Fredens Europa (Århus: Munch \& Lorenzen, 2014), 100.

18 OECD, Review af den danske folkeskole, 68ff; 141ff.

19 Korsgaard, Kristensen \& Siggaard, Pcedagogikkens idehistorie, 361. 
transnational 'netværks-styring af uddannelsesområdet', ${ }^{20}$ hvor der udøves et policy-pres på nationale uddannelsessystemer. ${ }^{21}$

\section{b) Pædagogiske konsekvenser: videns-problemet}

Den ovenfor beskrevne udvikling har konsekvenser for den almene pædagogiks konstitutive videns-problem. Dette problem handler nærmere bestemt om en antinomisk spænding mellem nøerhed og distance. Nøgtern professionalitet rummer nødvendigvis en distancering i sig, fordi professionel faglighed på den ene side må hvile i en forskningsforankret, objektiverende (teoretisk, teknisk) vidensbase. Her overfor står så på den anden side en pædagogisk-professionel viden kultiveret i nære, situerede relationer. Dette handler om det personbårne engagement som eks. elever forventer at finde i pædagogen eller underviserens menneskelige nærhed og involvering.

Der findes altså professionsviden udviklet gennem involverede praksiserfaringer (nærhed) og der findes professionsviden udviklet som teoretisk abstraktion $\mathrm{i}$ afstand til den konkrete praksis (distance). I dag forventer elever, klienter og andre brugere i det pædagogiske system, at møde professionelle, der trækker på begge vidensdimensioner, (selvom disse principielt er gensidigt udelukkende modsætninger). Den pædagogiske professionalitets vidensbase har traditionelt afgrænset sig selv i en refleksion af vidensformer der indbefatter dette antinomiske spændingsforhold mellem videnstyper i hele spektrummet fra det nære til det distancerede. Vi ønsker med andre ord at møde professionelle der både rummer en faglig og nøgtern, forskningsbaseret viden, men som også er menneskeligt autentiske og engagerede. Dvs. informerede af en solidarisk visdoms-viden.

Pædagogisk relevant viden spænder dermed over et spektrum af videntyper: tavs viden (det man ikke ved at man ved); praksisviden (det man erfaringsmæssigt ved der virker); professionsviden (praksisnær, metodisk refleksion); forskningsviden (abstrakte teorier eller grundlagsproblemer eller datadrevet evidensinformerede anvisninger). Pædagogikkens refleksion over sin egen vidensbase i hele denne spændvidde er konstitutiv for vedligeholdelsen af autoriteten og legitimiteten af den viden som undervisere og pædagoger handler på basis af i deres praksis. Dette er altså et spørgsmål om at beskytte den pædagogiske professionalitets fordring om, at hvile på et vidensfelt med en indre antinomisk enhed. Altså kravet om at handle på basis af en specifikt afgrænset kundskab defineret af den nævnte paradoksalitet i modsætningen mellem nærhed og distance.

Men med genbeskrivelsen af viden som vare, bl.a. i tilknytning til transnationale organisationsnetværks (OECD, konsulenthuse) styrende kobling ind i uddannelsessektoren afbrydes denne refleksion. Man ser nu en distanceret (statistisk) vidensform dominere og udgrænse de kundskabstyper der traditionelt er blevet udvikle i det nære (situerede, invol-

20 Stephen Ball \& C. Junemann. Networks, New Governance and Education (Bristol: The policy press, 2012), 129-143.

21 B. Lingard, \& S. Rawolle. "New scalar politics: Implications for Educations Policy," Comparative education 47, no. 4 (2011): 489-502; B. Lingard \& S. Sellar. "Globalization, edu-business and network governance: the policy sociology of Stephen Ball and rethinking education policy analysis," London review of education 11, no. 3 (2013): 265-280. 
verede, praksisnære vidensformer). På distinktionsniveauet vinder med andre ord distancen over nærheden. Dermed nedprioriteres kontekstuelle videnstyper. Et eksempel på dette er OECDs afdemokratiserede 21st century skills, der i dag bliver didaktiseret via Klafki og ligger til grund for C21 skoler. ${ }^{22}$

\section{Læring (mellem pligt og frisættelse)}

\section{a) PISA og OECD}

En organisation som OECD har fået et betydeligt impact på uddannelse globalt set. ${ }^{23}$ Med sit rent økonomiske perspektiv adskiller OECD sig fra eks. UNESCO, der baserer sine uddannelses-surveys på en moralsk betoning af solidaritet og menneskerettigheder. OECD består af 34 af de rigeste lande i verden og har ca. 2500 medarbejdere. OECD omsatte for 526 millioner $\$$ i $2013 .^{24}$

OECDs policyudvikling er forankret et netværk af eksperter, konsulenter, forskere, policyudviklere samt embedsfolk fra medlemslandene. ${ }^{25} \mathrm{Og}$ den højeste myndighed er det såkaldte Council der består af kredsen af medlemslandenes finansministre. Næste led i hierarkiet er en række 'direktorater' for hver af de hovedområder som OECD beskæftiger sig med. Det er bl.a. områder som skat, employment, videnskab, teknologi samt for nylig også uddannelsesområdet. ${ }^{26}$ Dette område blev opgraderet til et selvstændigt direktorat så sent som i 2013.

OECD går oprindelig tilbage til midten af det 20. århundrede. Men med PISA-programmets igangsættelse i år 2000 nærmest genopstår OECD i en 2.0 udgave. Baggrunden for dette er, at OECD op gennem 1990'erne sætter sig på uddannelsesområdet og dette område eleveres som nævnt til direktorats-højstatus område i 00erne. Udviklingen tager for alvor fart i 2008/09 hvor PISAs aktiviteter ekspanderer voldsomt, i tilknytning til at den globale opmærksomhed omkring PISA pludselig vokser eksponentielt.

Sammenlignet med IEA og UNESCO er OECDs PISA-program den ubestridte top-dog inden for global uddannelsesstyring. PISAs sammenligninger interesserer sig for at måle output, ressourceforbrug og effektivitet, for herved at identificere svagheder eller mangler, der efterfølgende kan gøres til genstand for politiske reformer.

Af nedslagspunkter i etableringen af dette paradigme er det vigtigt at se, at EU først iværksætter systematisk indsamling og komparering af uddannelsesdata fra og med PISAprogrammet begyndende i 2000. Men allerede med Maastricht traktaten (1993) er EU i gang med at regulere og standardisere forhold omkring medlemslandendes skole og uddannelsesanliggender.

22 Jeppe Bundsgaard. "Er dansk stadig et dannelsesfag?." In Cursiv, edited by Krogh \& Holgersen (Sammenlignende fagdidaktik 4, nr. 16, Aarhus Universitet 2016), 89-112.

23 Meyer, Strietholt \& Epstein, Three models of global education quality, 146.

24 Op.cit., 144.

25 Op.cit., 138.

26 Op.cit., 138. 
PISA er OECDs statistiske lokomotiv for kvantitativ undermuring af den uddannelsespolicy som OECD udvikler og distribuerer nationalt. Andreas Schleicher er leder af OECDs uddannelsesdirektorat og samtidig leder af PISA. Man bearbejder i OECDs PISA-program store mængder statistiske data, hvor ambitionen er at generere et evidensbaseret, videnskabeligt grundlag, hvorpå nationale skolesystemer kan sammenlignes. Man laver målbare indikatorer for enkeltdele i helheden, hvorved komplekse helheder nedbrydes i dele. Disse numeriske værdier kan dernæst sammenlignes i et konkurrenceperspektiv. Skolen objektiveres her i en målbar 'input - output' logik og instrumentaliseres dermed som leverandør af humane ressourcer til arbejdsmarkedet.

Den definitionsmagt der her erobrer retten til at bestemme uddannelsessektorens konditioner, dens succeskriterier og dens bærende logikker kommer ud af en teknisk, statistisk og økonomisk viden. Den viden der her lægges til grund for denne revolutionering af uddannelsessektoren, er altså præget af ikke-pædagogiske vidensformer. EU og OECDapparatets kontrol og styring af nationale uddannelsessystemer er omfattende, ${ }^{27}$ til trods for at skole og uddannelse formelt set altså falder uden for EU's jurisdiktion.

Skolerne bliver imidlertid med Lissabon traktaten (2007) centralt fokuseret af EU. Det er denne traktat der nu giver Europa-kommisionen mandat til at regulere uddannelsesområdet. ${ }^{28}$ | 2007 undermures tillige unions-tanken, idet man i praksis ophæver de nationale grænser med bestemmelsen om unionsborgerens fri bevægelighed (Schengen traktaten). Samtidig understreges unionens interesse for at bestyrke den europæiske dimension på tværs af skolesystemer med programmer som ESHA (for skoleledere) og ERASMUS (for studentermobilitet). Disse programmer spiller sammen med hele OECDs transnationale uddannelsesdagsorden. Også med Bolognaprocessen (1999) ${ }^{29}$ understøtter EU og OECD gensidigt hinanden. Målet med Bologna er at standardisere alle videregående uddannelser i Europa, mhp. at understøtte studentermobilitet og arbejdskraftens fri bevægelighed.

Frem til indgangen af 1990erne var der intet ønske om at komparere uddannelse globalt i OECD. I de tidlige 1990ere blev globale, standardiserede evalueringsformater (som PISA, PIRLS og TIMMS) afvist af OECDs uddannelsesdepartement som værende af "dubious validity" ${ }^{30}$ Den transnationale vending indtræffer imidlertid efterfølgende op gennem 1990ernes indløb mod PISA-programmets initiering i 2000.

Med PISA opstartes i 2000 et løbende treårigt, globalt kompareringsprogram. Man udtrækker kvantitative indikatorer som nøgletal for nationale uddannelsessystemer, for at sammenligne disse systemers performativitet i en transnational optik: PISA 2000, 2003, 2006, etc. Dette programs løbende flow af kvantitativt standardiseret materiale der kan sammenlignes, har fået en meget betydelig politisk gennemslagskraft.

27 Korsgaard, Kristensen \& Siggaard, Pcedagogikkens idehistorie, 359.

28 Moos, Pcedagogisk ledelse i en laringsmålstyret skole, 55.

29 Bologna er en reformproces for videregående uddannelser, der blev påbegyndt i 1999.

30 OECD citeret i Meyer, Strietholt \& Epstein, Three models of global education quality, 139. 
Et forhold at være opmærksom på her er PISA programmets grundlæggende policy-orientering. Det er bemærkelsesværdigt at den i bund og grund økonomiske (dvs. uddannelseseksterne) organisation OECD får så stor indflydelse på uddannelsessektoren. Ikke bare med PISA men også med de heraf afledte policy analyser som eks. Education policy analysis (2002) samt Review af den danske folkeskole (2004). I disse nationale reviews følges der op på PISA-runderne med detaljerede anbefalinger fra OECD til de nationale centraladministrationer. PISA leverer dermed data som feed in til transnational policy-udvikling. PISA er således ikke en neutral instans, men fungerer som leverandør af data ind $i$ et politiserende styringsprogram orkestreret af OECD (og undermuret af EU).

I et videnskabeligt-kritisk perspektiv er det helt fundamentalt, at OECD med denne policy orientering dermed pådrager sig en legitim skepsis ift. hvorvidt PISA-programmet i dets afrapportering samt i dets metoder og design er farvet af bias, der hidrører fra OECD og EUs uddannelsespolitiske målsætninger med programmet. Dels er det OECD der financierer PISA og dels har EU og OECD opbygget en indbyrdes afhængighed blandt andet i form af gensidig udveksling af store mængder uddannelsesdata. PISA-data kan her mines og screenes op imod de kulturelle og financielle data for hver medlemsstat, som EU har adgang til. ${ }^{31}$ Et eksempel på denne alliance er Europa-kommissionens publikation 2017 Tilstandsrapport for uddannelse i Danmark, der baserer sig på OECDs PISA data.

Man kan karakterisere dette som en videnspolitik, hvor ambitionen er at sammensmelte den uddannelsesvidenskabelige forskning med policy og styring. Dvs. PISA selviscenesætter sig på den ene side som en neutral (kvantitativ) videnskabelig uddannelsesevaluering. På den anden side er PISA (som ejet og styret af OECD) dybt involveret i den politiske styring af selvsamme uddannelsesfelt som den evaluerer. De nationale uddannelsesreviews med vidtgående anbefalinger er bygget op på PISA-data. Dette dobbeltbogholderi (af påtaget neutral og kvantitativ (selvdeklareret) objektivitet sammenblandet med politisk regulering) er selvsagt problematisk i et videnskabeligt perspektiv.

Humlen i dette projekt er ideen om et evidensbaseret, videnskabeligt grundlag for policyudvikling. Dvs. man kobler et specifikt videnskabeligt grundlag (statistisk metrik - med de muligheder og begrænsninger denne tilgang har) ind i en allerede eksisterende politisk proces. Eks. i OECD (2007) Evidence in education - linking research and policy.

OECDs kvantitativt-statistiske alliance med politikudvikling er som sagt en videnspolitisk hybrid, der samtidig udgør rygradden i det globale brand som OECD er blevet. Det politiske system og medierne har taget OECD til sig som en næsten uimodsigelig darling. En nærmest absolut reference for hvad der er god uddannelse og dårlig uddannelse. Hver ny PISA-afrapportering er i Danmark nærmest en national begivenhed.

Gennem sammenligning af statistiske indikatorer for uddannelsessystemers performativitet standardiseres de respektive nationalstaters uddannelsessektorer gennem OECDs 
distribution af statistisk evidensbasering som policy for uddannelse og forskning. Eks. i OECD (2010) Evidence informed policy and practice in education in Europe.

Dermed samtykker man i 'systemet' stiltiende til mindst to implicitte betingelser som PISA forudsætter. Dels (i) er evident uddannelsesviden (som der styres på basis af) lig med privilegering af en kvantitativ, statistisk vidensform (andre vidensformer er udeladt uden nogen forklaring). Dels (ii) er reformer og ændringer i sig selv godt (dvs. det gamle og velafprøvede er i sig selv dårligt, uden der gives nogen yderligere forklaring). I OECD Governance in Transition. Public management reforms (1995) lyder den helt generiske anbefaling også, at der $\mathrm{i}$ al almindelighed skal implementeres reformer. Det er indikatorerne på en revolution der taler her.

\section{b) Pædagogiske konsekvenser: handlings-problemet}

Den ovenfor beskrevne udvikling har konsekvenser for pædagogikkens konstitutive handlings-problem. Dette problem handler nærmere bestemt om en kantiansk spænding mellem friscettelse og pligt. Og dermed om hvordan man kan handle pædagogisk således at man understøtter læringsprocesser.

For megen pligt og topstyring vil skabe autoritære eller uselvstændige pædagoger eller meget monologisk orienterede undervisningsformer. I universitetspædagogisk sammenhæng vil for megen styring tillige skabe uautentiske institutionsrepræsentanter og en sådan ensidig styringslogik vil understøtte en disciplinær type af pædagogisk tilgang med direkte eller indirekte fastlåsning af de studerende eks. (i universitetspædagogisk sammenhæng) via tydelige pensum-restriktioner eller med forelæsningsmarkerede korrekte meninger, som det i realiteten ikke er muligt for de studerende at bryde med, uden at ekskludere sig selv fra 'det gode selskab'.

For megen pædagogisk frisættelse kan omvendt blive udtryk for en falsk tillid til den studerende, der siger 'du kan selv'. Dette risikerer at ende i en pædagogisk ansvarsforflygtigelse og et svigt af det professionelle ansvar. Frisættelse og pligt (styring) hviler med andre ord i et antinomisk modsætningsforhold. Den pædagogiske tilrettelæggelse og vurdering af læringsprocesser forløber inde i dette spændingsfelt. En kantiansk myndighedspædagogik vil på den måde i en (universitets-pædagogisk) undervisningssammenhæng også arbejde $\mathrm{i}$ en sådan antinomisk spænding. Dels i den a) styrende indretning af et pensum i form af en kernelitteratur, som den studerende er forpligtet på. Dels b) gennem den samtidige, frisættende opfordring til frie valg af fordybelsesområder hvor den studerende udfolder 'sit eget' perspektiv.

Handlings-problemet handler om, at den pædagogisk professionelle er henvist til, at realisere og virkeliggøre sine pædagogiske intentioner, ud fra ønsket om at kunne påvirke de studerende; uden dog nødvendigvis at kunne dette. Enhver effekt af vores handling foreligger først som formidlet gennem den studerendes egen bearbejdning. Dette indebærer at vi i vores handlinger og kommunikation må afspejle antagelsen af, at der skulle være en kausalitet fra vores undervisning til den studerendes læring; selvom der $i$ udgangspunktet 
ingen kausalitet er givet. Men man er ikke desto mindre henvist til at handle i tillid til dog at kunne gøre en forskel.

De transnationale organisationers indflydelse på uddannelsessystemet i form af måling af læringsudbytte (PISA) betjener sig af statistisk komparering. Dermed veksles den gamle kantianske og frihedsbaserede myndigheds-pædagogik (med sin grundspænding mellem frisættelse og pligt) til en mere global, lighedsbaseret, målrationel og teknisk tilgang til læring. Målrationel, teknologisk lærings-styring dominerer dermed friheds-dimensionen på distinktionsniveauet. Et eks. er den læringsmålstyrede folkeskole, der henter sin logik fra den transnationale kompareringsdagsorden. ${ }^{32}$ Styringen vinder dermed over frisættelsen, med den effekt at læreprocesserne af-pædagogiseres. Dvs. der sker en teknologisering. Dvs. handlings-problemet mister sin pædagogiske dybde og spændstighed og bliver dermed til procedural metode afledt fra policy (eks. i form af undervisningsvejledninger på den ministerielle EMU portal der indirekte sætter metodefriheden under pres).

\section{Autenticitet (mellem individualisering og standardisering)}

\section{a) Demokratisk deficit}

EU og OECDs standardiseringsdagsorden realiseres under et banner af 'kvalitetssikring'. Denne kvalitet skal (som nævnt) sikres ved - gennem PISA - at evaluere den konkrete skolepraksis på en målbar måde, så denne kan sammenlignes transnationalt. Uddannelseskvalitet er dermed (uden nogen yderligere begrundelse eller refleksion) defineret som det i en pædagogisk proces der a) er fælles med alle andre lande og som b) kan omdefineres til en numerisk værdi. For sådanne indikatorer kan bruges til styring (af målopnåelse) og det ved man meget om i OECD. Hvorvidt og i hvilket omfang dette også kan bruges ind i predagogisk meningsfulde processer opholder man sig i mindre grad til.

Her henter man op gennem 00'erne evidens-begrebet ind fra den medicinske sektor til brug i uddannelsessektoren. ${ }^{33}$ Dette handler om, hvad det er for metoder der virker og hvilke der ikke virker ift. til læringsopnåelse. Den evidens man ønsker lagt til grund, bestemmes som en erfaringsvidenskabelig information sikret ad eksperimentel-forskningsmetodisk vej. Der gør sig dermed et naturvidenskabeligt forbillede gældende. Iflg. Biesta registreres dermed:

" ... et stærkt ønske om eksperimentel forskning der - iflg. fortalere for evidensbaseret undervisning - er den eneste metode, der er i stand til at tilvejebringe sikker evidens for 'hvad der virker' ...."34

32 Keld, Skovmand. Uden mål og med - forenklede føelles mål? (København: Hans Reitzel, 2016).

33 Søren Christensen \& John Krejsler. Evidens - kampen om viden der virker (København: FOA, 2015).

34 Gert Biesta. God uddannelse i målingens tidsalder (Århus: Klim, 2011), 41. 
Hersessom det førstea) at man i transnationalt regiønsker at ændre uddannelsesforskningen. Man ønsker en af-teoretiseret uddannelsesforskning orienteret efter "positivistiske antagelser". ${ }^{35}$ Denne videnskabsteoretiske position flyder ind i OECDs ønske om, at definere uddannelsesforskningen meget snævert som en form for databehandlende myndighedsbetjening. Dvs. hvor policy og forskning tendentielt flyder sammen. Dermed bringes policy-niveau og forskningsniveau ind i en gråzone af uskelnelighed. Denne ambition er beskrevet i OECD (2007) Evidence in education - linking research and policy. Aflæggere af dette ses også i forskellige systemteoretiske aftapninger af uddannelsesforskning.

Det andet led i dette er, at man ønsker b) at ændre den pædagogiske praksis, ved også at rykke denne ind på et evidensbaseret grundlag. Dvs. man ønsker at måle sig til, hvad der er best practice. ${ }^{36}$ Kriteriet for hvilken undervisningspraksis der er 'den bedste' udgøres af effektivisering ift. de standarder der er lagt af PISA. Fokus bliver derfor lagt meget smalt på målopnåelse af policy- og detailstyrede trinmål og slutmål for læring (orienteret af transnationale standarder som C21).

Man kunne også vælge for skolen at den burde arbejde langt bredere med den helhedsopgave der hedder civilisations-genskabelse. Dette ville handle om at komparere skolen med det omgivende civilsamfund som er en helt anden opgave. Men beslutningskraften flyttes - med de transnationale organisationer - væk fra dette demokratiske niveau nede i den folkelige, kulturelle opinion og rykker i stedet opad mod et globalt niveau (administreret af OECD og EUs statistikere, økonomer og jurister). Dette er iflg. Biesta et demokratisk problem. Og dette demokratiske problem fortsætter ind i de transnationale organisationer.

OECD ledes således ikke på basis af demokratiske principper (som eksempelvis UNESCO gør det) men i stedet af finansielle principper, efter devisen jo rigere et land er, jo mere bestemmer det. ${ }^{37}$ Dvs. hvis du er lille og fattig har du intet at skulle have sagt. OECDs beslutningsprocedure er dermed lukket om sig selv. Symptomatisk herfor er medlemslandendes demokratiske offentligheder også afskåret fra indflydelse på OECD.

Selvom OECDs kerneydelse ift. uddannelse bl.a. er at frembringe og distribuere evidens, kvalitetssikring og evaluering, så er OECD ikke selv accountable. Dvs. OECD praktiserer ikke selv det som de prædiker. OECD er ikke pligtig til offentligt at dokumentere, at de forvalter deres mandat ansvarligt ift. de nationale skolesystemer de intervenerer i. OECD er mao. ikke accountable ift. faglige professionsvurderinger af OECDs uddannelses-bidrag. Nationale aktører som fagdidaktikere, statistikere, embedsfolk har ikke noget mandat overfor OECDs uddannelsesdirektorat. ${ }^{38}$ Og OECD er heller ikke accountable ift. demokratisk kontrol med karakteren af OECDs nationale anbefalinger. Ikke desto mindre er nogle uddannelsesforskere begejstrede for OECDs kompetence-kataloger.

\footnotetext{
Op.cit., 42.

Christensen \& Krejsler, Evidens - kampen om viden der virker.

Meyer; Strietholt \& Epstein, Three models of global education quality, 139.

Op.cit., 146.
} 
Men den demokratiske vinkel bliver alt andet lige utydelig her og erstattes af en økonomisk logik. OECDs tætte parløb med globale konsulentvirksomheder (som Pearson) er veldokumenteret og et godt eksempel på dette demokratisk forfald. ${ }^{39}$

\section{b) Pearsson}

Nærmere bestemt er opgaven med at udvikle PISA af OECD givet i kommission til konsulenthuset Pearsson. Pearsson har ca. 40.000 medarbejdere og omsatte i 2014 for ca. 80 milliarder kroner. Pearsson er involveret i OECDs nationale uddannelsesreviews hvor PISA og IEA uddannelsesdata lægges til grund for OECDs interventioner i nationale skolesystemer. ${ }^{40}$ Endvidere er Pearsson involveret i udviklingen af testværktøjer designet til OECDs PISA-kompetencemål. Gennem sådanne engagementer trækker Pearsson via sine software produkter Big Data om læring, skole og uddannelses- systemer i 60 forskellige lande på globalt plan. ${ }^{41}$ Gennem statistisk bearbejdning af disse enorme mængder uddannelses-data kan der mines empiriske mønstre, der siger noget om forholdet mellem styring og læring globalt. Denne type informationer bearbejdes med den primære ambition for øje, at effektivisere den respektive nations skole og uddannelse. Alt dette videreudvikles løbende af Pearsson i form af testværktøjer og læringsprogrammer, der som services kan afsættes globalt. Man kan mene at ejerskabet til sådanne udannelsesdata måtte ligge i de nationalstater hvis uddannelsessystemer informationerne trækkes fra. Men det er tværtimod Pearsson der har ejerskabet til disse data. ${ }^{42}$ Denne enorme vidensressource omhandlende uddannelsessystemer i hele verden er dermed på private hænder i en monopollignende tilstand.

Dette er et eksempel på fremkomsten af en global "Education Service Industry" faciliteret af private konsulenter, rådgivere, forskere, sparringspartnere, der profitbelagt sælger policy-løsninger, evalueringer og kvalifikationssystemer, læringsprogrammer til nationalstater over hele verden. Konsulenthuse brander sig nu via deres engagement i OECD som "globale læringsvirksomheder". ${ }^{43}$ Pearssons konsulenter har endda i nogle lande overtaget opgaven med at eksaminere eleverne. ${ }^{44}$ På baggrund af de nationale skoletraditioner som vi har eksempelvis i Danmark, kan det virke besynderligt defensivt, at man politisk i så høj grad de sidste 20 år har afgivet initiativet til disse transnationale organisationer og deres læringsorienterede konsulenter.

Det er vigtigt at se, at konsulenthusene har en interesse i den standardisering af uddannelsessektoren som OECDs PISA-program er udtryk for. For med transnationalt standardiserede uddannelsesprogrammer får konsulenthusene adgang til produkter der profitbelagt kan afsættes overnationalt, dvs. globalt. På en skole i Bagsværd, i Peru eller i Algeriet kan

39 Lingard \& Sellar, "Globalization, edu-business".

40 Op.cit., 273.

41 Moos, Predagogisk ledelse i en laringsmålstyret skole, 82-84.

42 Moos, Padagogisk ledelse, 83.

43 Meyer, Strietholt \& Epstein, Three models of global education quality, 140.

44 Moos, Padagogisk ledelse i en laringsmålstyret skole, 343. 
samme PISA-alignede produkt afsættes. Det lyder som enhver købmands drøm. Dette betegnes i forskningslitteraturen som "Edu Business". .5 $^{2}$

Denne edu business er tæet knyttet til en principiel metodologisering, der gør det muligt via koncepter, at overflytte kvalitetssikringsprogrammer på tværs af sammenhænge og nationale kontekster. Dermed får man et salgbart produkt der via trademarkede koncepter (eks. herhjemme PALS, CL, Læringsstile, LP) kan markedsføres som færdige pakker, kits eller køreklare prototyper. ${ }^{46}$ Risikoen er her igen at pædagogiske processer bliver indsnævret omkring et teknisk-globalt fokus på output og ressource-effektivisering. Og at den egentlige pæedagogiske forståelse af hvad der er hensigtsmæssigt og menneskeligt ønskværdigt i en konkret pædagogisk proces, dermed bliver overskygget af en managementlogik, hvor fokus mere kommer til at ligge på ledelsens behov for at demonstrere styring, effektivitet og handlekraft gennem partnerskaber med trademarkede aktører fra det private erhvervsliv.

Det der går tabt med disse magtforskydninger er den grundlæggende 'tykke' forståelse af skole og pædagogik, som der hvor vores fælles kulturelle gods bliver genskabt på tværs af generationerne. Denne genskabelse handler om det meget lange træk dybt i den civilisatoriske pædagogiks ubevægede tid, hvor de uløselige spørgsmål om tillid, risiko, dømmekraft, det gode liv, kritik, ydmyghed, demokrati og ansvar (alle de dybe ord der skaber afmagt i os) ligger og rumsterer. Og her kommer de trademarkede læringsskabeloners effektmålinger til kort. Fordi de bygger på en standardisering, der renser kulturelle, historiske, moralske, religiøse og politiske sammenhænge ud af den pædagogiske kabale.

Dette fælles kulturelle idegods har traditionelt rakt ind i skolen 1) dels via den professionsfaglighed der skaber skolen i undervisningen; og 2) dels via samfundets løbende demokratiske samtale om 'folkets skole'. Men disse udtryk for national, kulturel selvbestemmelse omkring skolen som kulturinstitution kobles altså ud af ligningen med den transnationaltkomparative vending.

Herhjemme i Danmark kan man også genkende dette demokratiske deficit i form af en mere generel tendens til, at konsulenthuse, private tænketanke og strategisk nedsatte råd vinder frem, medens pædagogiske fagfolk, forskere og interesseorganisationer med rod ned i skolens folkelige undergrund og civilsamfund får sværere og sværere ved at gøre sig gældende i de politiske lovforberende processer hvad angår uddannelsessektoren fra dagtilbud til universitet. ${ }^{47}$ Her er der et demokratisk deficit på nationalt niveau centreret omkring Moderniseringsstyrelsen, som ligger under Finansministeriet. Denne styrelse er tæet knyttet til OECD, Europa-kommisionen og Edu-business feltet og dermed også de glo-

45 Lingard \& Sellar, "Globalization, edu-business”; G. Thompson, G.C. Savage \& B. Lingard. "Think tanks, edu-businesses and education policy: issues of evidence, expertise and influence," The Australian Association for Research in Education 43 (2016): 1-13.; S. Lewis. "Policy, philantrophy and profit: the OECDs PISA for schools and new modes of heterarchical educational governance," Comparative Education 53, no. 4 (2017): 518-537.

46 M.S. Hansen \& T. Iskov. "Hvordan kan pædagogiske koncepter blive pædagogiske?," Unge Pæedagoger, nr. 1 (2013): 6-18.

47 Rumford, "European civil society"; Vesnic-Alucevic \& Nacarino, "The EU and its democratic deficit". 
bale konsulenthuse. ${ }^{48}$ Men dette deficit henviser altså blot til et deficit et niveau højere, på det transnationale plan.

Det er EU's abstrakte globaliserings-principper og OECDs teknisk-statistiske logik der undermurer denne af-demokratisering. Dette demokratiske deficit er symptomatisk for en tendens, hvor pædagogikken gradvist har løsnet sig fra det konkrete og livsnære og er trukket i retning af et mere og mere globalt perspektiv (som en teknisk, cost-benefit evaluerings-disciplin). Dermed fremtræder evt. nationalt-folkelige indsigelser og bekymringer i sigende grad som en irrelevant obstruktion af et større globalt sigte. 'Det transnationale' er en ny, hellig vision. Et techno-evangelium der udvikles i overnationale institutionsnetværk med fokus på global markedsøkonomi og vækst - passende indhyllet i en pseudo-religiøs sentimentalisering af humanisme og rettigheder. Det overstatslige institutionsnetværk er dermed knyttet til et demokratisk deficit. ${ }^{49}$

\section{c) Pædagogiske konsekvenser: Institutions-problemet}

Den ovenfor beskrevne udvikling har konsekvenser for pædagogikkens institutions-problem. Dette problem handler nærmere bestemt om det konstitutive spændingsforhold mellem individualisering og standardisering i det pædagogiske forhold, - og dermed også om den professionelles mulighed for at fastholde en pædagogisk autenticitet.

Uddannelsesinstitutioner fungerer og hænger sammen i kraft af de udmønter et regime, der på forskellige måder ensarter og rationaliserer handlingsanvisende rammer for alle institutions-aktørers adfærd. Heroverfor står den enkelte studerende med sit ikke fikserede læringspotentiale og sit behov for en fri, dannende læreproces. Dette afsætter spørgsmålet om det overhovedet er muligt, at institutionalisere (og dermed standardisere og regelrette) læringsprocesser i deres egenskab af at være individuelt åbnede og dermed uregerlige? Således kan læreren ikke vide om hendes udlevede plan i undervisningen rent faktisk understøtter de pædagogiske målsætninger hun har. Institutioner der giver undervisning, må gennem didaktik, læreplansteori og gennem iagttagelse af egen formåls- og begrundelses-dimension løbende reflektere denne modsætningsstruktur mellem på den ene side a) institutionens nødvendige regime af standardisering og ensretning af alle aktører ud fra fælles retningslinjer; og på den anden side b) tilgodese den individualiserede og unikke læringsproces og dens iboende behov for frihed og autonomi i udfoldelsen. Dette antinomiske spændingsforhold har den almene pædagogik traditionelt reflekteret som et konstitutivt element i sit eget fundament. Denne refleksion (af en antinomisk modsætning mellem standardisering og individualisering som nødvendige dimensioner i en institutionaliseret ydelse) sætter sig i den professionelles refleksion af sin egen autenticitet som institutions-repræsentant.

48 Se hertil God arbejdsgiveradfcerd i staten (Moderniseringgstyrelsen 2015) sammen med Mckinsey.

49 Lasch, Eliternes oprør, del Il; Rumford, "European civil society"; Vesnic-Alucevic \& Nacarino, "The EU and its democratic deficit". 
Med den ovenfor beskrevne, transnationale komparerings-revolution og top-down styring, da forskubbes imidlertid denne antinomiske balance mellem standardisering og individualisering, der berører den professionelle institutionsaktørs autenticitet. Dimensionen af standardisering vinder dermed (på distinktionsniveauet) over den dimension af unik individualisering som læreprocessen også er nødig. Et symptom på dette er, at topstyrede institutioner redefinerer eller direkte reducerer de professionelle institutionsaktørers autenticitet. Et eksempel er effekterne af det oplevede demokratiske deficit de sidste 10-15 år ift. eks. grundskole og universitetsområdet..$^{50}$

\section{Dannelse (mellem enhed og pluralisering)}

\section{a) Human kapital}

Hvis mennesket ikke selv er målet med de pædagogiske processer, men mere et middel der indgår målrationelt i forhold til opnåelse af andre målsætninger, så begynder værdigrundlaget for en pædagogisk praksis at skride. For så er formåls- og dannelsesdimensionen ved at svinde ind. Det der oprindelig var mål, bliver nu et middel. Risikoen for dette er i dag reel, fordi det ikke længere er indlysende, at mennesket i dag er mål og centrum i de moderne samfundsprocesser. I dag gør andre kategorier mao. mennesket rangen stridig som det mål der styrer de samfundsmæssige processer. Det kan eks. være mål som penge, magt, information, natur, territorium, ressourcer, viden, energi, mv.

At pædagogikken som samfundsmæssig delproces også kan overtages af denne logik, ser man i den aktuelle situation, hvor det etisk-humanistiske menneskesyn (fra den klassiske oplysningpædagogiks fase) i dag erstattes af et nyt mere busines- og ressourceorienteret ideal om human kapital. OECD definerer human kapital som:

“Den viden, de færdigheder, kompetencer og egenskaber kropsliggjort af individer, der faciliterer skabelsen af personlig, social og økonomisk velvære".51

Det enkelte menneske udgør med alt hvad det er, en totalitet bestående af sine kognitive evner, menneskelige egenskaber, sin faglige viden og færdigheder og personlighed. Totaliteten af dette udgør en ressource, der har en markedsværdi. Totaliteten af hvad det hele menneske er blevet til i sit livsløb betragtes dermed af OECD som en antropoid kapitalform. En kapitalform der netop er blevet til de sidste 25 år:

"Sit globale uddannelsespolitiske gennembrud fik begrebet humankapital ... i begyndelsen af 1990erne. Her blev den oprindelige teoris individuelle investeringsopfattelse udvidet i forhold til de komparative fordele, som virksomheder og nationer har ved øget investering i uddannelse i en global og vidensbaseret økonomi ... / teorien [blev] overtaget af OECD

50 Stephen J. Ball. "Professionalism, managerialism and performativity”. In Professional development and educational change, edited by Leif Moos \& John Krejsler (København: Danmarks Pædagogiske Universitets Forlag, 2003), 23-44.

51 OECD, Education policy analysis, 119. 
og lagt til grund for organisationens stærkt forøgede uddannelsespolitiske engagement fra midten af 1990erne og frem".52

Man ser her, at den komparative vending bygges op og løber parallelt med et nyt og mere teknisk-kalkulerende menneskesyn. Teorien om human kapital overtages af OECD præcis på det tidspunkt, hvor denne rent økonomiske organisation (for økonomisk samarbejde og udvikling) beslutter sig til at intervenere i uddannelsessektoren. OECDs PISA programmer der måler og komparerer, er altså elementer der indgår i den nationale generering af human kapital til den globale vidensøkonomi, som det eks. ses i OECD (1996) Measuring what people know. Human capital accounting for the knowledge economy. ${ }^{53}$

OECDs målsætning om videns-økonomisk vækst installerer dermed en ny mennesketype, der er en mere individualiseret, kalkulerende og opportunistisk markedsaktør, der strategisk forvalter sine ressourcer. Det etisk-humanistiske menneskebillede tilbage fra den oplysningsbaserede pædagogik og den nyhumanistiske dannelsesperiode forekommer her helt udvisket. Dette må også ses på baggrund af EU-installationen af en ny identitetsmæssig overbygning på Europas befolkning. Nemlig "unions-borger"-identiteten. Med Maastricht traktaten (1993) er man nu borger i en union. Den human-kapitaliserede diskurs er blot OECDs policy-udmøntning af EU's identitetspolitik.

Det gamle ideal: mennesket som etisk humanitas-væsen var kulturforankret ind i konkrete steder i verden og var dermed overleveret et tilhør til egne regionale sæder, skikke, traditioner, overleveringer. Dette var en overlevering til moral og vise leveregler, skabt gennem den historik der knyttede sig til konkrete generationers liv et bestemt sted i verden. Dvs. til en moralsk selv-lovgivning. Til en frihed under loven. Og der var en egen historik, der samtidig var fortællingen om loyalitet og tillid til ens verden. Dette var den oplysningshumanistiske vendings menneskebillede.

Den humane kapitals individ er i modsætning hertil i dag det ressourcegjorte intetstedstilhør for det moderne selv. En ressource er omstillingsparat, fleksibel, mobil. Den hører ikke til. Den er defineret gennem sin flydende omstillingsparathed. Global bevægelighed bliver nøglen til økonomisk velstand og dermed social mobilitet. Den humane kapital er opportunistisk, kalkulerende og entreprenant. Det er den globale markeds-spiller par excellence. Der må dermed insisteres på en klar distinktion mellem den klassiske pædagogiks dannelsesbegreb og EU og OECDs forankring i human kapital.

Dette er samtidig indikativt for fortællingen om hvordan 'det inter-nationale' (relationen mellem nationale regeringer) er blevet erstattet af 'det trans-nationale' (global netværks-

52 Korsgaard, Kristensen \& Siggaard, Pcedagogikkens idehistorie, 377-378.

53 Bolognaprocessen indfører bl.a. standardiseringen af et system af credit points der kvantificerer arbejdsmængden tilknyttet et givet uddannelsesforløb. Behovet for kompetitiv human kapital er drivkraften for EU's transnationale edu policy. Derfor må den valorisering der lægges ned i systemet af credit points (ECTS) undermures af en standardisering af outputtet; dvs. læringen. Dette gøres med Bolognas kvalifikationsramme, der kompetencebeskriver læringsmål for al videregående uddannelse (viden og færdigheder og kompetence). Da kilden til legitimitet for EU's edu policy er økonomisk konkurrencedygtighed, da er outputtet pr. definition genstand for optimering, dvs. læringsmål bliver styrende. På den måde er Bolognas ECTS reform og den mere målrationelle lærings-diskurs knyttet til hinanden. Denne sammenknytning beror på et ideal om sammenlignelighed mhp. ressourceoptimering. 
styring). Det 'inter-nationale' handlede om et europæisk samarbejde mellem demokratisk valgte regeringer i suveræne nationalstater, som et samarbejde siden heden-old baseret på de respektive, nationale sindelag. Europa var det territorium, hvor suveræne nationalstater gennem århundreder var forpligtet på hinanden i gensidigt respektfuldt samarbejde på godt og sandelig også på ondt.

Det 'transnationale' optager imidlertid 'det inter-nationale' i sig og omsætter det i en global netværksstyring. Konsekvensen er ønsket om en EU-union uden civilisatoriske markører eller kulturel forankring. Det er en bevægelse "from a cultural to a financial focus" som det direkte hedder. ${ }^{54} \mathrm{Når} E U$ eks. udnævnte det islamiske Istanbul til at være 'Europas kulturhovedstad' (dvs. som centrum for europæisk kultur) i 2010 er der intet galt i det! Det er blot en markering af, at alle metropoler - også eks. Beijing - kan være kulturhovedstæder i EU. For alt er økonomi. Og EU er som union en markering af et fleksibelt netværk, der ikke levner plads til at der skal være noget kulturelt centrum eller geografisk tilhør. Unionens referent er således ikke Europa i hendes kulturhistoriske hjerte. EU's referent er det globaltplanetariske marked. Og denne trans-nationalisering er undermuret af en EU og OECDkoordineret global uddannelsesrevolution baseret på et nyt menneskesyn.

\section{b) Pædagogiske konsekvenser: værdi-problemet}

Den ovenfor beskrevne installation af et nyt menneskesyn med fokus på human kapital har konsekvenser for pædagogikkens grundlæggende normproblem. Dette problem handler nærmere bestemt om en antinomisk spænding mellem normativ pluralisering eller normativ enhed. Pædagogikkens normproblem udspiller sig traditionelt i denne refleksion af forholdet mellem værdimæssig enhed og værdimæssig pluralisering.

Dette problem handler om, at det ikke giver mening samfundsmæssigt at insistere på, at specifikke normer og common-sense forståelser skal fungere som hierarkisk målestok for identifikationen af almene pædagogiske værdier ${ }^{55}$ (udover de juridisk givne meget brede minimumsnormer). Men ikke desto mindre vedbliver det virkeligt første i pædagogikken med at være umiskendeligt normativt. Ikke mindst har praktikere behov for en følelse af at kunne 'trække på samme hammel' og bidrage til et fælles værdiprojekt. Dette er et paradoksalt behov midt i samfundets eskalerende pluralisering, hvor det bliver sværere og sværere at pege på nogle samlende og stiftende værdier (andet end det som der er dom for ved byretten).

Pædagogiske processer er dog altid normative, fordi det der kendetegner pædagogiske handlinger er, at de er båret af en intention om at påvirke, forme, indvirke, gribe ind, forbedre i en eller anden form. Men hvorfra kommer de værdier der er bærende for de interventioner der definerer handlinger som pædagogiske? Kommer de fra læreren eller

54 OECD, Education policy analysis, 4.

55 Pædagogikken har med andre ord fået et normativitets-problem. Jf. Kristensen \& Laursen, Gyldendals pæedagogik håndbog, 544; samt Vejleskov, Hans \& Thyge Winther-Jensen. De predagogiske fags grundlag og anvendelse (Århus: Århus Universitetsforlag, 2017). 
pædagogens uddannelsessocialisering, fra den professionelle som privatperson, fra institutionen, fra ledelsen, fra de skattebetalende forældre, fra samfundet eller fra forskningen? Med andre ord: er disse værdier vi funderer os på af pædagogisk, etisk eller videnskabelig karakter? Er begrundelsen pædagogisk, så kan refleksionsrammen eks. være lære- eller dannelsesteoretisk. Dannelsestemaet er overskriften over ca. 2000 års europæisk åndshistorie. Men som tema er dette begreb udfordret i dag i spændingen mellem en fortidsrettet og fremtidshenvendt dimension. Dette forstået på den måde, at en pædagogisk praksis i et vist omfang har brug for at kunne trække på et fortidsforankret hierarki af common sense forståelse, der refererer til former for konsensus, som en fælles kulturel verden må forankre sig i som traditionsoverlevering. Men samtidig bliver denne omverden hver dag mere uoverskuelig, global og polycentrisk. Og i kølvandet på denne pluralisering indtræffer som konsekvens heraf en nødvendig værdi-relativering. Men da normproblemet ikke kan afskaffes, da bliver dannelsesteorierne en ressource for pædagogisk professionelles løbende refleksion over det normative grundlag for deres konkrete praksis og den pædagogiske betydning af denne.

Denne antinomiske modsætning i det normative kan beskrives således: For meget værdimæssig enhed vil på den ene side resultere i monokulturel pædagogik eller helt homogeniserede, autoritære institutionskulturer. For megen pluralisering vil på den anden side gøre pædagogikken til et rent spejlbillede af elevens eller brugerens ønsker. Elevens eget perspektiv bliver dermed styrende for pædagogikken. Den pædagogiske formålsdimension bliver dermed uklar og den egentlig pædagogiske sammenhæng i det der foregår bliver utydelig. For megen værdimæssig pluralisering risikerer også at opløse pædagogikkens indre enhed og reducere den til teknisk metode (af angst for normativ substans).

Man har her at gøre med det pædagogiske grundproblem, at vi er henvist til at handle pædagogisk ud fra, at der er basale, almenmenneskelige værdier der informerer vores pædagogiske handlinger. Det er blot blevet mere prekært at fastholde disse værdier som reelt forpligtende for elever eller studerendes egen proces og ejerskab. I det moderne uddifferentierede samfund er der ikke et entydigt pædagogik-begreb, der kan sikre sådanne specifikke værdier som stiftende og alment forpligtende for alle. Pædagogikken har traditionelt i dannelsesteorierne reflekteret dette modsætningsfyldte værdiproblem.

Men med den humane kapital bryder dette antinomiske spændingsforhold mellem værdimæsssig enhed og pluralisering sammen. Humanoid kapital er nemlig pluraliseret enhed eller enhedsliggjort pluralisering. Med denne transformation bryder den hidtidige distinktioner sammen. Pluralisering vinder over det enhedslige i distinktionen.

\section{Konklusion}

I PISA er det kun indikatorer der genfindes i alle de 72 lande der kan indgå i målingerne og dermed tillægges vægt. Da konkurrence-perspektivet og dermed komparationen er det 
bærende i PISA, kan indikatorer der afspejler nationalt unikke forhold ikke indgå i PISA..$^{56}$ PISA kommer dermed tendentielt til at modarbejde uddannelsessystemernes kulturelt genskabende funktion og fremmer i stedet med komparations-programmer (som understøttelse af policy) globale, tekniske redskabsfærdigheder som kompetencebeskrevet læring. ${ }^{57}$

Dette er et eksempel på, at vi i den komparative vending er gået fra en oplysningshumanistisk pædagogik til en OECD-styret non-civilisatorisk uddannelses-styring. Denne aktuelle tilgang har ingen kulturel-normativ kerne og ender derfor i dag som en grå, statistisk topstyring, udøvet af anonyme bureaukrater, der fra Brussel (EU) og Paris (OECD) fordrer Moderniseringsstyrelsen med statistisk undermurede policy-anbefalinger. I tråd hermed er der opbrud i vort fælles vokabular. Ud glider gamle ord som 'opdragelse' og 'dannelse'. Og ind kommer begreber om 'ledelse' og 'statistik' som markører af en ny 'edudiskurs'. I dette lys bliver det på sigt nok nødvendigt at beskytte de civilisatoriske og kulturbærende skolefag mod yderligere reformer fra OECDs side. Dvs. fag der har at gøre med habituerende kundskab som etik, kunst, musik, samfundsfag, historie, og kristendom.

OECDs stærke, økonomiske og standardiserende fokus på de nationale uddannelsessystemer og de tilhørende pædagog- og læreruddannelser udgør en form for deterritorialisering af pædagogikken. I kontrast hertil er den almene pædagogik knyttet til en genskabelse af en civilisatorisk livsform. Denne livsform ligger indbagt i kulturelle praktikker, moralske standarder og historiske sammenhænge. Disse livssammenhænge har siden heden old vævet i de af pædagogikkens konstitutive modsætningsforhold, der er nævnt ovenfor (videns-, institutions-, handlings, og værdi-problemet). Disse for pædagogikken konstitutive grundproblemer aflejrer sig (som vist) i en common sense forståelse af pædagogiske begreber som professionalitet, laring, autenticitet og dannelse. Disse begreber har traditionelt været knyttet til en dybde ( $\mathrm{i}$ form af en antinomisk spænding) på den måde, at de har været bærere af den almene pædagogiks ovennævnte, konstitutive grundproblemer. Det er her der som vist, i disse år foregår en transnational udtynding af den antinomiske pædagogik-tænkning, der undermurer de fire ovennævnte pædagogiske kernebegreber. Ift. disse fire begreber sker der en af-pædagogisering, i den forstand, at den modsætningsfyldte grundspænding begreberne er bærere af, bliver afviklet af det statistisk-komparative styringsparadigme. Det er altså en sådan almen pædagogik og dens reproduktion af vor civilisatoriske livsform der bliver udvisket med ambitionen om transnational, statistisk styring af uddannelsessektoren. Det der undergraves her er forståelsen af pædagogik som en livsgenskabende praksis, der sammenføjer hævdelsen af kulturel autonomi med territorial suverænitet. Den aktuelt stærkeste filosofiske undermuring af en sådan kritik af det transnationale projekt finder man hos den senere Peter Sloterdijk ${ }^{58}$ gennem hans inspiration

56 Stephan, Hoppmann. "Epilogue." In PISA zufolge PISA - PISA according to PISA, edited by Hoppmann, Brinek \& Retzl (Wien: LIT-Verlag, 2007), 363-400.

57 For den danske grundskoles vedkommende se Skovmand, Uden mål og med. Samt et mere internationalt perspektiv Lingard \& Rawolle, "New Scalar Politics".

58 Peter Sloterdijk. Zorn und Zeit: politisch-psychologischer Versuch (Frankfurt a.M.: Suhrkamp, 2006), 315-352. 
fra Heidegger og Nietzsche. ${ }^{59}$ Herudover kan der også peges på Rüdiger Safranski. ${ }^{60}$ Det vil imidlertid føre for vidt inden for rammerne af nærværende artikel, at redegøre for disse bidrag og deres indbyrdes sammenhæng.

Har den ovenfor skildrede, transnationale uddannelsesrevolution så haft nogen indvirkning over de sidste 20 år i Danmark? Et centralt sted at kigge hen er her til læreruddannelsen og pædagoguddannelsen, fordi det er her fremtidens professionelle i bl.a. skole og dagtilbud bliver uddannet og dermed formet. Her kan man se til de to professorer Hans Vejleskov og Thyge Winther-Jensen, der begge har forsket de sidste 40 år i bl.a. skole, pædagogik og didaktik. De taler i 2017 med bekymring om den "store omskiftelighed" med hensyn til hvad undervisningen i pædagogik i dag rummer på de pædagogiske uddannelser. Og der konkluderes i et tilbageskuende blik på perioden 1995-2015 at:

" ... nyuddannede stort set ingen viden har til fælles med kolleger, der er uddannet mindre end 20 år før". ${ }^{61}$

Dette er en klar markering af, at man her ser én konsekvens af det kraftige deficit der angår den almene pædagogiks position og status. De to professorer markerer her en tydelig bekymring over et registreret opbrud i denne 20-årige tidsperiode, hvad angår a) en øget usikkerhed omkring pædagogikkens teoretiske status (pædagogikkens videns-problem) samt b) en heraf udløst øget historieløshed i det pædagogiske felts aktuelle selvrefleksion (pædagogikkens værdi-problem). Altså en afkobling af pæedagogikkens teoretiske-humanistiske rod ned i en almen, historisk overleveret tradition. Hele deres bog handler om denne problematik på de pædagogiske professionsuddannelser. Dermed intervenerer de i pædagogikkens institutions-problem.

Dermed bidrager Vejleskov og Winther-Jensens studie til at underbygge den ovenstående analyses centrale påstand: at én specifik effekt af den transnationale uddannelsesrevolution de sidste 25 år er, at almene grundtræk i pædagogikken sættes under pres eller direkte opløses. Under et slør af selvdeklareret neutralitet bidrager denne transnationale uddannelsesstyring til, at udtynde den almene pædagogiks grundbegreber. Dermed bliver det gradvist vanskeligere, at forstå den almene pædagogiks forankring som kulturopgave.

59 Peter Sloterdijk. Im Weltinnenraum des Kapitals: für eine philosophische Theorie der Globalisierung (Frankfurt a.M.: Suhrkamp, 2005), kap. 12, 19.

60 Rüdiger Safranski. Hvor meget globalisering tåler mennesket? (København: Akademisk, 2004).

61 Vejleskov \& Winther-Jensen, De pæedagogiske fags grundlag og anvendelse, 11. 